Pak. j. sci. ind. res. Ser. A: phys. sci. 201154 (3) 117-122

\title{
Underground Coal Gasification Studies on Chakwal Coal, Punjab, Pakistan
}

\author{
Rashid Mehmood*, Muhammad Habib, Muhammad Arif Bhatti, Asia Yousaf \\ and Shahid Tufail Sheikh \\ Coal Technology Section, Mineral Processing Research Centre, \\ PCSIR Laboratories Complex, Ferozepur Road, Lahore-54600, Pakistan
}

(received September 20, 2010; revised March 11, 2011; accepted April 11, 2011)

\begin{abstract}
Underground coal gasification (UCG) experimentation was carried out on low-rank lignite coal of Eastern Salt Range, Chakwal, Punjab Province, Pakistan. A simulation reactor was designed in laboratory environments and gas input volume, type of gas input, gasification linkage and mode of combustion were investigated. Geological characteristics of the coal were also studied. The composition of emitted gases was evaluated and the syngas having calorific value of $2.42 \mathrm{MJ} / \mathrm{m}^{3}$ was produced.
\end{abstract}

Keywords: underground coal gasification, lignite, combustion, gas composition, Chakwal

\section{Introduction}

Coal is a valuable fuel resource and is far more abundant than oil or gas. It is burned to produce heat which is used for various purposes. The most significant uses are in electricity generation, steel production, manufacture of cement, fertilizers and paper, preparation of liquid fuels, synthetic natural gas, methane, ammonia and hydrogen gas in alumina refineries and in pharmaceutical industries (Prebstein and Hicks, 1982).

Coal gasification is a technology of converting coal into combustible gas by reacting it with controlled amount of air (oxygen) and water (steam) at high temperature. The resulting gas mixture, called synthesis gas or syngas, is itself a fuel which can be used for industrial heating. Currently a number of coal gasification technologies are being used in the world. However, underground coal gasification (UCG) has recently emerged as a technology for coal conversion and utilization (Kostur and Blistanova, 2008). It is carried out in non-mined coal seam, which is deep-underground, using injection of oxidants and bringing the product gas to surface through production wells, drilled from the surface. UCG can produce syngas at $1 / 2$ to $1 / 4$ of the cost compared to the surface gasifier (Khadse et al., 2010; Blinderman and Anderson, 2004).

Mining is the most common method for extraction of coal associated with constraints and disadvantages of mining. Surface mining is economical only when the coal seam is nearer to the surface. UCG offers an

*Author for correspondence; E-mail: rashidgeologist@hotmail.com alternate technique to conventional methods and can be applied to deep and uneconomical resources to extract (Ghose and Paul, 2007). Compared to traditional coal mining and gasification, the UCG technology has the advantages of low plant cost, less environmental impact and absence of coal transport (Shuqin and Junhua, 2002). However, the presence of seam at a depth of 30 to $800 \mathrm{~m}$ having thickness of more than $5 \mathrm{~m}$ with minimal discontinuities are the basic requirements for UCG (Turner and Liu, 2004).

Siemens (1868) first suggested the underground gasification of waste coal left in the mine. Later on, many significant researchers took part in the development of this technology. In 1989, European Working Group recommended that a series of trials should be undertaken to evaluate the commercial feasibility of UCG. The trials were undertaken by the UK and Belgium, and were supported by the European Commission. The largest ongoing programme is being conducted by China, which includes 16 UCG trials. The successful demonstration of UCG during 1999-2003 at Chinchilla town in Australia resulted in gasification of around 35,000 tonnes of coal (Blinderman and Anderson, 2004).

Pakistan has large estimated deposits of over 185 billion tonnes of low quality lignite to sub-bituminous coal of tertiary age. Only the Punjab Province has 235 million tonnes of coal reserves located in the Eastern and the Central Salt Range and in Makerwal area of Surghar Range. Coal seams of economic value are present locally in Dandot area in the Eastern Salt Range and belong to the Patala Formation of late Paleocene (Shah, 1977). 
Main objective of the present study was to develop a viable process for exploitation and utilization of large unmineable coal reserves of lignite located in District Chakwal of Punjab Province, Pakistan. Hence, the potential of UCG process for clean coal technology of Chakwal lignite was investigated and experiments were carried out in laboratory environments with multiple options. A comprehensive account of experimentations and the results obtained are presented here.

\section{Materials and Methods}

The proximate analysis of coal and combustion products was performed in accordance with ASTM (2007) methods. Gross calorific value was determined by Parr Isoperibol Bomb Calorimeter (Model: 6200). Total and sulphate sulphur was determined gravimetrically while pyrite sulphur was estimated by stoichiometric combination with iron. Organic sulphur was calculated by subtracting the sum of sulphate and pyrite sulphur from the total sulphur. Chemical compositions of the representative sample of coal and the typical combustion products are presented in Table 1 and Table 2, respectively.

Laboratory scale UCG experiments were performed on lignite coal of Durmeyal area, Tehsil Choa Syden Shah, District Chakwal, Pakistan which is easily available. The size of coal used was $100 \%$ down 1" $(2.54 \mathrm{~cm})$ mesh sieve. A simulation rectangular shaped reactor was designed to cover almost all the conditions of underground coal gasification. A site having length $210 \mathrm{~cm}$, width $90 \mathrm{~cm}$ and height $90 \mathrm{~cm}$ was prepared for UCG experiments within the boundary of the Mineral Processing Research Centre, PCSIR Laboratories Complex, Lahore. The coal bed of $90 \mathrm{~cm}$ thickness $(200 \mathrm{~kg})$ was placed in the first layer for installation of equipment for heating. Afterward, two adjacent stainless steel seamless pipes of $213 \mathrm{~cm}$ length and $2.5 \mathrm{~cm}$ diameter were inserted vertically into the bed as inlet pipes to pass oxygen and fresh air, simultaneously. Another pipe of similar length with $3.8 \mathrm{~cm}$ diameter was inserted on the other end at the distance of $150 \mathrm{~cm}$ from each other for outlet. The connectivity (channel) between inlet and the outlet pipes was made by passing pressurized oxidants (air $\sim 700 \mathrm{kPa}$ and oxygen $\sim 250 \mathrm{kPa}$ ) into the coal bed. Two electrical heaters of 1200 Watt each were placed into the coal bed for initial ignition of coal; $50 \mathrm{~cm}$ long thermocouples with temperature range of $0-1600{ }^{\circ} \mathrm{C}$ were inserted between both the heaters to measure temperature inside the coal bed during experiments. As a second step, a layer of $30 \mathrm{~cm}$ thickness coal $(800 \mathrm{~kg}$ ) was again introduced to make a total coal bed of $120 \mathrm{~cm}$ thickness $(1000 \mathrm{~kg})$. The reactor was covered with clay and soil. The coal bed was ignited electrically under controlled conditions to start gasification. The initial ignition was set for $2 \mathrm{~h}$ using oxygen gas; and after coal starts burning itself, the gasification ran for $8 \mathrm{~h}$ using air injection.

Table 1. Proximate analysis of coal before burning

\begin{tabular}{ll}
\hline \hline Constituents & Amount (\%) \\
\hline Moisture content & 3.38 \\
Volatile matter & 24.50 \\
Ash & 44.93 \\
Fixed carbon & 21.20 \\
Organic sulphur & 2.63 \\
Pyrite sulphur & 1.89 \\
Sulphate sulphur & 1.34 \\
Total sulphur & 5.85 \\
Gross calorific value & $14.30 \mathrm{MJ} / \mathrm{kg}$ \\
\hline \hline
\end{tabular}

Table 2. Chemical composition of ash

\begin{tabular}{ll}
\hline \hline Constituents & Quantity (\%) \\
\hline Silica $\left(\mathrm{SiO}_{2}\right)$ & 55.76 \\
Aluminum oxide $\left(\mathrm{Al}_{2} \mathrm{O}_{3}\right)$ & 10.10 \\
Iron oxide $\left(\mathrm{Fe}_{2} \mathrm{O}_{3}\right)$ & 30.4 \\
Sodium oxide $\left(\mathrm{Na}_{2} \mathrm{O}\right)$ & 0.25 \\
Potassium oxide $\left(\mathrm{K}_{2} \mathrm{O}\right)$ & 0.77 \\
Calcium oxide $(\mathrm{CaO})$ & Nill \\
Magnesium oxide $(\mathrm{MgO})$ & 0.116 \\
Phosphorous oxide $\left(\mathrm{P}_{2} \mathrm{O}_{5}\right)$ & 0.13 \\
Sulphate $\left(\mathrm{SO}_{4}\right)$ & 1.617 \\
\hline \hline
\end{tabular}

The temperature variation of coal was continuously measured. The reactor was connected with air compressor, which supplied air through the air inlet to reactor during the process. A gas flow meter (Model: SW 100) was used to measure the volume of air input flowing to the reactor. The air flow rate was maintained at $\sim 70 \mathrm{dm}^{3} / \mathrm{min}$. The gasification was continued for total $10 \mathrm{~h}$. Gas from the experiment was sampled by gravitation method using a glass made gas sampling tube (length $30 \mathrm{~cm}$, diameter $5 \mathrm{~cm}$ ). The sampling was repeated on hourly basis during the gasification process so that there were 8 gas samples for one experiment in 
each reactor. The combustion gases were analyzed using electrochemical and IR sensing device (Eurotron 8000 Greek). The calorific value of gas was calculated based on the percentage of $\mathrm{CO}, \mathrm{H}_{2}$ and $\mathrm{CH}_{4}$ contents.

Four experiments were conducted during this study. In the first experiment, only air was used and coal was moistened by water, whereas in the second experiment, a mixture of air and steam was applied to the coal. In the third experiment, the effect of linkage through the coal bed was investigated while in the fourth experiment, the steam and air flow direction was changed.

\section{Results and Discussion}

Proximate analysis of the representative sample of coal presented in Table 1 shows the ash content in coal is less than $45 \%$ which is sufficient to exploit it for UCG to produce syngas on commercial scale. Fixed carbon $(21.20 \%)$, volatile matter $(24.50 \%)$ and gross calorific value of coal (14.30 MJ/kg), show the coal, lignite in nature. However, the presence of 5.86\% sulphur appeared to be the main objectionable impurity. Nature of sulphur in composite sample of coal shows that it contains $2.63 \%$ organic, $1.89 \%$ pyrite and $1.34 \%$ sulphate sulphur. The high iron oxide content in the ash also indicates the presence of considerable amount of inorganic sulphur mainly in the form of iron pyrite and sulphate (Table 2). Proximate analysis of coal, left after burning, presented in Table 3 shows that fixed carbon has been reduced from $19.20 \%$ to $2.74 \%$, volatile matter from $24.50 \%$ to $3.72 \%$ and gross calorific value of coal from $14.30 \mathrm{MJ} / \mathrm{kg}$ to nil.

The coal used in this study is of Patala Formation which conformably overlies the Lockhart Limestone and transitionally overlain by the Nammal Formation in the Salt Range (Warwick et al., 1990). Based on the sections and borehole data, the formation consists of shale and marl with subordinate limestone, sandstone and coal.

Table 3. Proximate analysis of coal after burning

\begin{tabular}{ll}
\hline \hline Constituents & Amount (\%) \\
\hline Moisture content & 1.05 \\
Volatile matter & 3.12 \\
Ash & 93.09 \\
Fixed carbon & 2.74 \\
Total sulphur & 4.05 \\
Gross calorific value & No ignition \\
\hline \hline
\end{tabular}

The shale is dark greenish to grey in colour, at some places it is carbonaceous and calcareous. The limestone is white to light grey and nodular. It occurs as interbeds. Subordinate interbeds of yellowish brown and calcareous sandstone are present in the upper part. The thickness of the seam varies and is generally the thickest in south towards anticlinal core and the thinnest in the north towards synclinal axis of the Potwar synclinorium. It is $27 \mathrm{~m}$ thick at Khewra Village and $90 \mathrm{~m}$ at Patala Nallah.

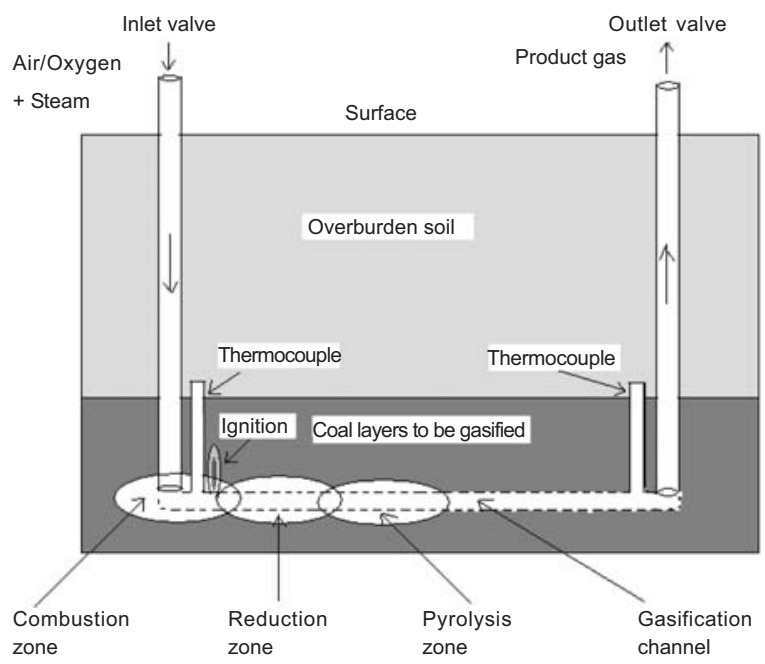

Fig. 1. Schematic representation of an underground coal gasification (UCG) reactor.

It has been observed the combustion is initiated at the bottom of the inlet hole by oxygen and then it is maintained by the continuous injection of air in between inlet and outlet holes, in the underground reaction zone (Fig. 1). As the coal face burns, the immediate area is depleted and the mixture of gases comes out from the outlet hole. Yang et al. (2002) explained that in the initial reaction zone (combustion zone), carbon dioxide is generated by the reaction of air with the coal. Afterward, carbon dioxide reacts with coal (reduction zone) to produce carbon monoxide. In addition, at high temperature (pyrolysis zone), moisture inherent in the coal bed also reacts with the coal to produce carbon monoxide and hydrogen:

$$
\begin{array}{ll}
\mathrm{C}_{\text {(coal) }}+\mathrm{O}_{2} \rightarrow \mathrm{CO}_{2} & \text { (Combustion) } \\
\mathrm{C}_{\text {(coal) }}+\mathrm{CO}_{2} \rightarrow 2 \mathrm{CO} & \text { (Reduction) } \\
\mathrm{C}_{\text {(coal) }}+\mathrm{H}_{2} \mathrm{O} \rightarrow \mathrm{CO}+\mathrm{H}_{2} & \text { (Pyrolysis) }
\end{array}
$$

The results of first underground coal gasification experiment, conducted using air as oxidant and water 
for moisture, have been summarized in Fig. 2. The quality of syngas produced in term of calorific value has been given in Fig. 6. It is obvious from this figure that the produced gases had a heating value of 1.19$1.56 \mathrm{MJ} / \mathrm{m}^{3}$ which indicates the product gas belonged to low-Btu category. The reason is that the injection of air only raises the nitrogen content and reduces the heating value of the product gas through reduction in the percentage of combustible gases i.e. hydrogen $\left(\mathrm{H}_{2}\right)$, carbon monoxide $(\mathrm{CO})$ and methane $\left(\mathrm{CH}_{4}\right)$ during the gasification process.

The results of second underground coal gasification experiment, performed through introducing the air along with super heated steam $\left(400-450^{\circ} \mathrm{C}\right)$ in the inlet hole, are presented in Fig. 3. It is clear from this figure that the amount of gases produced in the second experiment is higher than the amount of gases obtained from the first experiment. Consequently, the calorific value of

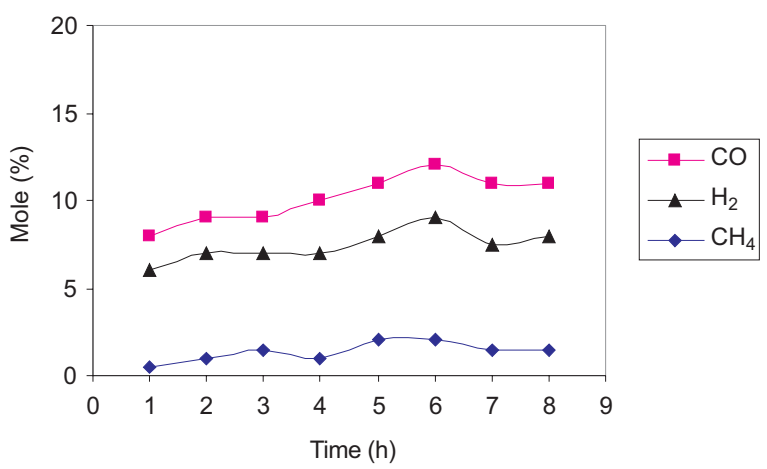

Fig. 2. The composition of gases obtained from UCG experiment with air (conducted without steam, channel and reverse combustion).

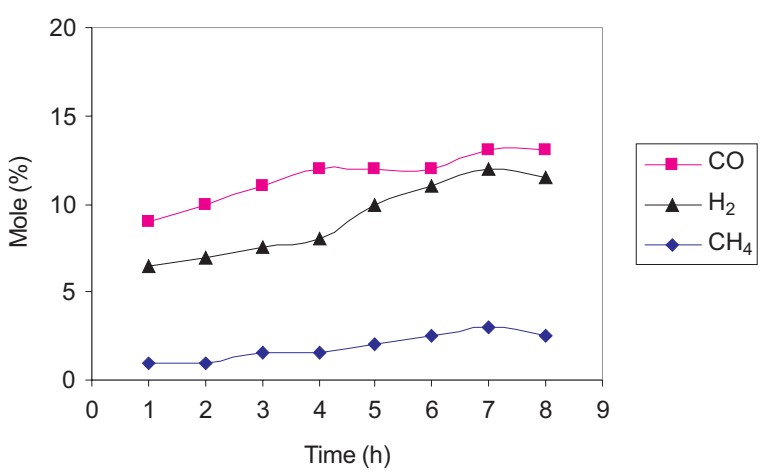

Fig. 3. The composition of gases obtained from UCG experiment conducted with air and steam (without channel and reverse combustion). gases (1.34-2.01 MJ/m³) obtained from the second experiment is better as compared to the calorific value of gases from the first experiment (Fig. 6). The reason is the injected gas used in this experiment is air and super heated steam. The injected steam reacts with carbon monoxide at $>800^{\circ} \mathrm{C}$ which is produced during the gasification process to form additional hydrogen. This step, also called as shift conversion, sets up the proper ratio of gases for the next step called methanation (Yip et al., 2007; Shuqin et al., 2003). The hot gases thus produced are passed through the coal bed which boosts up the percentage of methane in the resultant gases making a relatively high-Btu gas to the exit holes.

$$
\begin{array}{ll}
\mathrm{CO}+\mathrm{H}_{2} \mathrm{O} \rightarrow \mathrm{CO}_{2}+\mathrm{H}_{2} & \text { (shift conversion) } \\
3 \mathrm{H}_{2}+\mathrm{CO} \rightarrow \mathrm{CH}_{4}+\mathrm{H}_{2} \mathrm{O} & \text { (methanation) }
\end{array}
$$

The coal in natural state has generally insufficient permeability to enable air percolation necessary for efficient coal gasification. For successful coal gasification, a linkage to open up internal pathways in the coal bed was used. The result of gasification experiment conducted with gasification linkage inside the reactor shows that gasification process in the third experiment is better as compared with the gasification process in previous experiments (Fig. 4). The calorific value of the product ranges from $1.56-2.23 \mathrm{MJ} / \mathrm{m}^{3}$. This is due to the fact that pyrolysis and gasification of coal occurs at lower degree in the first and second experiments due to unavailability of gasification linkage inside the reactor. The ash, produced after initial coal burning, covers unburned coal which lies at the bottom of reactor due to gravitation effect. This condition is unfavourable for gasification process and consequently some part of the coal remains unburned, so that there is a loss of heat.

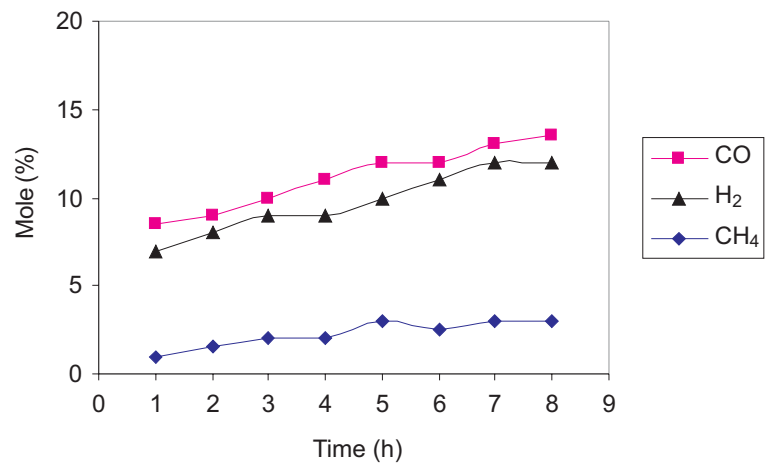

Fig. 4. The composition of gases obtained from UCG experiment conducted with air, steam and channel (without reverse combustion). 
The temperature along the bed is not high enough to maintain the reactions. This reduction in temperature has negative effect as shown by the amount and quality of gases produced. However, in the third experiment, due to availability of channel at the bottom of reactor, the burning of coal continues in right track and ash settles down in the bottom of reactor without interference in gasification progress (Perkins and Sahajwalla, 2006).

It was also found that success of the technique was dependent upon location of linkage in coal bed thickness relative to the bottom of the bed. The positioning of linkage low in the bed is extremely important as it allows gasification front to undercut coal as it moves from back to front after completion of linkage. The gasification linkage at the bottom of coal bed allows a better reaction to take place and the coal at bottom is initially consumed and then progresses to the upper part of coal seam. The combustion moves along the bed and as the void grows, unburnt coal falls into it creating a bed of coal rubble that is relatively reactive because of large surface area present (Blinderman et al., 2008; Jie, et al., 2008).

The results of UCG reverse combustion linkage experiment are shown in Fig. 5 and the quality of produced syngas in term of calorific value $\left(1.71-2.42 \mathrm{MJ} / \mathrm{m}^{3}\right)$ is given in Fig. 6. Air at $\sim 100 \mathrm{kPa}$ pressure was injected at the ignition hole to sustain a combustion zone. Then air injection was switched to adjacent hole. The injected air percolates through coal bed to ignition hole and the combustion zone proceeds to ignition hole i.e. toward the source of oxygen. Due to counter-current movement of injected air and combustion zone, a localized highly permeable pathway of carbonized coal is left behind. When combustion zone reaches injection hole, gasification zone expands around the injection hole until the full bed thickness was gasified between two adjacent holes.

The product gases of typical UCG process with air injection may have calorific values ranging from 4.0 to $5.5 \mathrm{MJ} / \mathrm{m}^{3}$, almost double of the value with oxygen injection, depending on the specific properties of coal and operating conditions (Yang, 2008). The calorific value of syngas produced at optimized conditions was found to be $2.42 \mathrm{MJ} / \mathrm{m}^{3}$. The achieved value is slightly on the lower side due to low quality of Chakwal coal. The temperature patterns of gasification experiments also show that gasification temperatures " $\mathrm{T}$ " in the first, second, third and the fourth experiment are in the ranges of $\left(302-285^{\circ} \mathrm{C}\right),\left(305-540{ }^{\circ} \mathrm{C}\right),\left(373-635^{\circ} \mathrm{C}\right)$ and $\left(390-695{ }^{\circ} \mathrm{C}\right)$, respectively. These data indicate that temperature measured in the first experiment is lower than the temperature of second experiment, which in turn is lower than the third experiment and so on.

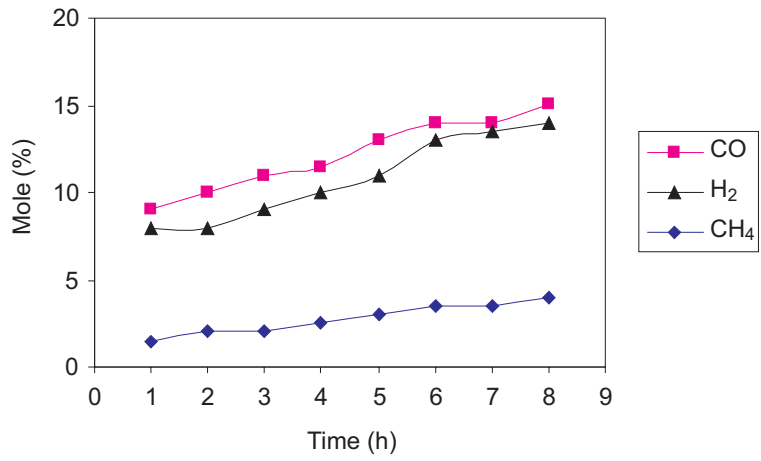

Fig. 5. The composition of gases obtained from UCG experiment conducted with air, steam, channel and reverse combustion.

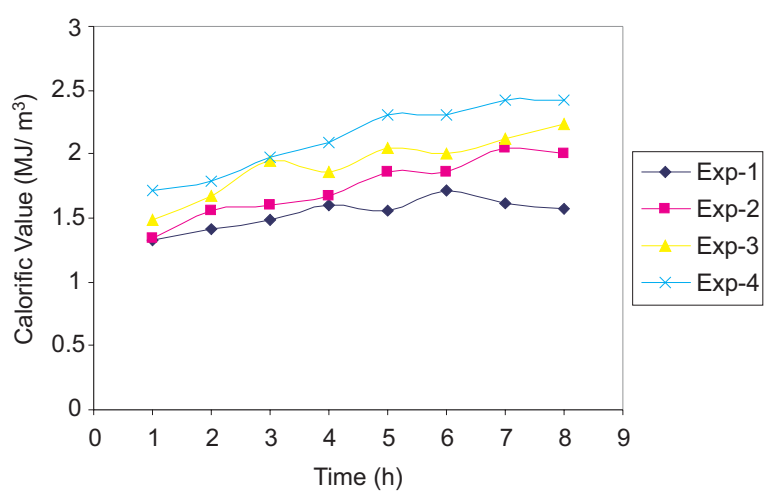

Fig. 6. The calorific value of gases obtained from different UCG experiments.

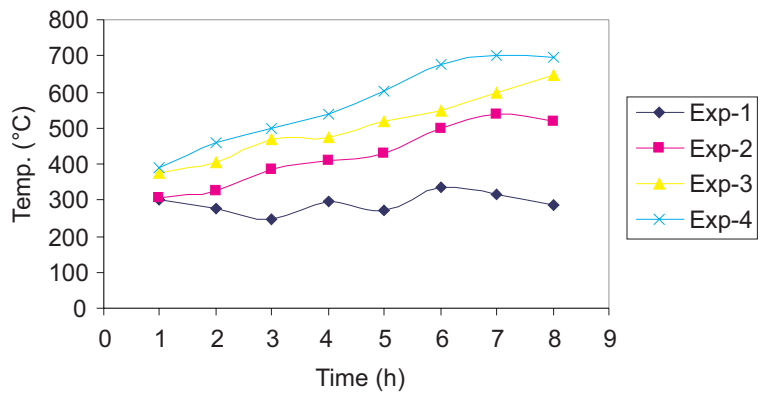

Fig. 7. The temperature pattern obtained from different UCG experiments. 
Besides that, the pattern of change in temperature during the course of gasification in the first experiment is quite different from that in other experiments. It was observed that in the first experiment, the pattern was irregular during the progress of gasification (Fig. 7). On the other hand, the pattern of temperature in other experiments had tendency of increasing with the progress of gasification experiment.

\section{Conclusions}

The results of investigation show that during underground coal gasification, conducted in laboratory using a simulation reactor; flow rate, type of injected gases, gasification linkage and the mode of combustion affect the production and quality of gases. Results of the first UCG experiment show that without using steam, gasification linkage and reverse combustion, fewer amounts of gases are produced. The calorific value of the gases produced in the first experiment is in the range of $1.19-2.01 \mathrm{MJ} / \mathrm{m}^{3}$, whereas in the second experiment - using steam along with air - it is in the range of $1.34-2.01 \mathrm{MJ} / \mathrm{m}^{3}$. The gasification process in the third experiment with linkage is more effective as compared to that in second experiment without it, as is evident by its calorific value of $1.56-2.23 \mathrm{MJ} / \mathrm{m}^{3}$. Similarly, the gasification process in the fourth experiment with reverse combustion linkage is better as compared to the process in third experiment without reverse combustion. The calorific value of gases produced in the fourth experiment ranged from 1.71-2.42 $\mathrm{MJ} / \mathrm{m}^{3}$.

\section{References}

ASTM 2007. ASTM Standard Practice for Proximate Analysis of Coal and Coke CD 3172-07, 2007, vol. 05.06, pp. 347-348. ASTM International, 100 Barr Harbor Drive, P.O.Box C700, West Conshohocken, USA.

Blinderman, M.S., Saulov, D.N., Klimenko, A.Y. 2008. Forward and reverse combustion linking in underground coal. Energy, 33: 446-454.

Blinderman, M.S., Anderson, B. 2004. Underground Coal Gasification for Power Generation: Efficiency and $\mathrm{CO}_{2}$ Emission. ASME Technical Paper PWR 2004-52036, March 2004, pp. 473-479. Proceedings of ASME, 2004 Power Conference (POWER 2004), March 30-April 1, 2004, Baltimore, Maryland, USA.

Ghose, M.K., Paul, B. 2007. Underground coal gasification: a neglected option. International Journal of Environmental Studies, 64: 777-783.

Jie, L., Meiyunting, W., Wenjun, L. Ming, Z. 2008.
Model test for underground coal gasification of Xinhe coal, China. Huagong Xuebao, 57: 29482992.

Khadse, A., Qayyumi, M., Mahajani, S.M., Aghalayam, P. 2010. Underground coal gasification: New clean coal utilization technique for India. Energy, (Oxford, United Kingdom), 32: 2061-2071.

Kostur, K., Blistanova, M. 2008. Research of UCG in Laboratory Workshop: Effective Utilization of Coal Resources and Advanced Technologies, TCE, Ankara, March 2008.

Perkins, G., Sahajwalla, V. 2006. A numerical study of the effects of operating conditions and coal properties on cavity growth in underground coal gasification. Energy Fuels, 20: 596-608.

Prebstein, R.F., Hicks, R.E. 1982. Synthetic Fuels, International Student Edition, McGraw-Hill Inc. Chemical Engineering Series, New York, USA.

Shah, S.M.I. 1977. Stratigraphy of Pakistan, vol. 12, 101 pp. The Geological Survey of Pakistan, Quetta, Pakistan.

Shuqin, L., Jie, L., Jian, C., Zhen, Y., Li, V. 2003. UCG model test of Huating coal with oxygen-steam as gasification agent. Journal of Southeast University (Natural Sciences Edition), 33: 355-358.

Shuqin, L., Junhua, Y. 2002. Environmental benefits of underground coal gasification. Journal of Environmental Sciences, 12: 284-288.

Siemens, C.W. 1868. On the regeneration gas furnace as applied to the manufacture of cast steel. Journal of Chemical Society of London, 21: 279-310.

Turner, C., Liu, J. 2004. Hydro-mechanical processes during in-situ coal gasification, $2^{\text {nd }}$ International Conference on the Sustainable Processing of Minerals, Australia, 2: 123-132.

Warwick, P.D., Shakoor, T., Javed, S., Mashhadi, S.T.A., Ghaznavi, M.I. 1990. Chemical and Physical Characteristics of Coal and Carbonaceous Shale Samples from the Salt Range Coal Field, Punjab Province, Pakistan: U.S. Geological Survey OpenFile Report 90-524, 44 pp.

Yang, L. 2008. Coal properties and system operating parameters for underground coal gasification, Part-A: Recovery Utilization and Environmental Effects, Energy Sources, 30: 516-528.

Yang, Z., Liang, J., Li, X.Z. 2002. Study of burning control system of underground coal gasification. Coal Conversion, 25: 32-35.

Yip, K., Wu, H., Zhang, D. 2007. Effect of inherent moisture in Collie coal during pyrolysis due to in-situ steam gasification. Energy Fuels, 21: 28832891. 